\title{
Impact of Population Growth on Nutritional Density and Food Security - A Spatio-Temporal Analysis of Ajay-Mayurakshi Interfluve, Birbhum District, West Bengal, India
}

\author{
Soumita Ghosh \\ Asstt. Prof., Hooghly Women's College, Hooghly, West Bengal.
}

\begin{abstract}
Food Security is undoubtedly a major concern and recently got topmost priority to the government. Over the various plan periods, our country has been working towards increasing agricultural production on one hand and developing an efficient mechanism for reaching food to every poor person in the most inaccessible conditions, on the other. The concept of Food Security implies that, all people at all times have both physical and economic access to the basic food they need (FAO, 1983). The study area selected for the present study is the interfluves of Ajay-Mayurakshi River, parts of Birbhum district in West Bengal. Geographically, interfluve of Ajay-Mayurakshi River is a part of ancient "Rarh Bhumi" of Bengal, having favourable agro-environmental condition. The proposed interfluve region is mainly rain fed and intensified by mono-cropped cultivation system, still suffers by inter-regional disparity in agricultural development. Though, the region has also a range of promising prospect in agriculture for the development of the proposed area. Growing population pressure has raised a considerable demand for adequate and quality supply of food. The present paper attempts to analyse the trends in population and its growth in the study area. It also discusses the pattern of nutritional density and food availability status during the last three census years. The major objective of the present study is to examine the trends in population growth and spatial distribution of the study area and to analyse the trends and spatial variations in nutritional density and identification of food surplus and deficit blocks within the study area. For this specific study modern methodology and techniques of interpretation will be taken into account for final inferences of the study.
\end{abstract}

Keywords: Population Growth, Nutritional Density, Food Security, Food Availability, Agricultural Productivity.

\section{Introduction}

The issues of Food security and nutritional density are now very much significant in the developing world and it is said to exist when all people, at all times, have physical, social and economic access to sufficient, safe and nutritious food that meets their dietary needs and food preferences for an active and healthy life (FAO 2009). It is undoubtedly a major and topmost prioritized subject to the government today with respect to not the availability of food only, but how much people are getting nutritious food in a particular unit and space also is the global concern. Food security is inherently interlinked with other current global challenges of economy and climate change. The concerned economic, environmental and especially scenario in climate change in recent years have a significant impact on global food security problems. Global as well as regional climate change impacts fundamental aspects of food security such as availability, stability, access and utilization of food which are major concern in relation to the present problem. Availability is a function of production, accessibility is related to purchasing power, utilization is determined by the availability of minimum basic needs and stabilization is influenced by the sustainability of production system and virtually all those are basic components of food availability and security. Essentially, the impacts of climate change on present scenario the productive agricultural land as well as productivity are likely to diminish food security in some places. Recent research suggests that, climate change will have major impacts on staple crops, especially in Asia and Africa, where widespread hunger, poverty and insecure food supply are major consequences. In this regard, food security, nutritional density and population growth (even or uneven) are closely linked with each other in the present nature of problem. The present study has been converged in the district of Birbhum, West Bengal which is not a traditionally backward but accelerated growth of population has also been registered in recent decades; but due to some distinct social problems proper food security with respect to optimal nutritional density has not been maintained to every member. 


\section{Major Objectives of the present study}

The major objective of the present study is converged on the impact of the accelerated rate of growth of population in relation to food security and nutritional density. In this regard, the research will also try to unfold the situation in the following aspects-

- To examine the existing size of population, rate of growth and spatial distribution pattern within the study area ;

- It has also tried to highlight the Linkages among Population growth, Nutritional density and food availability in relation to the holistic goal of development; and it is for the planners, administrators and academicians particularly regional geographers to have a proper assessment of the study area; and

- To analyse and interpret the trends and spatial variation of nutritional density and delineation of block which have surplus and deficit within the study area and finally, to get inferences on the major objective of the present research.

\section{Database}

The present study is based on both the primary and secondary data, collected and tabulated from different sources by qualitative and quantitative collection methods. Proper sampling, verification and ground checking were the significant modes of research and investigation. The data relating to population size and growth for four census years i.e. 1981, 1991, 2001 and 2011 have been collected from Directorate of Census Operations, West Bengal. The data related to relevant land use and agricultural production have been collected from Directorate of Land Records, West Bengal and PAO, Suri, Birbhum district, West Bengal for four consecutive years 1981, 1991, 2001 and 2011.The other important sources are agricultural Census and some unpublished records have also been consulted from the Directorate of Agriculture, West Bengal; Statistical Abstract, Agriculture and Livestock statistics, Census publications etc. Maps are extracted and prepared from reliable sources and others are compiled by the authors.

\section{Methods of Enquiry and Analysis}

Apart from qualitative and observational methods, present study has also been qualified by various quantitative measures to evaluate analysis and represent the central theme of research. Popular statistical and analytical methods have been employed for calculating the population and production concentration index and nutritional density of the study area which became finally most effective for getting inferences. However, the relative proportion of total population with respect to total cultivated land of each block has been computed by the following principles-

Spatio-temporal variation has been analysed and represented through analytical measures and proper methods of representation have been followed through updated GIS platform. For this specific study modern methodology and techniques of interpretation will be taken into account for final inferences of the study. Study Area

\begin{tabular}{|c|c|}
\hline$P C I=\frac{T P o}{T P o}$ & $\begin{array}{l}\text { lock } / T C_{R} A \text { of Block } \\
{ }_{T} / T C_{R} A \text { of } D_{T}\end{array}$ \\
\hline$P_{R} C I=\frac{T A P \text { of Block } / T C_{R} A \text { of Block }}{T A P \text { of } D_{T} / T C_{R} A \text { of } D_{T}}$ & 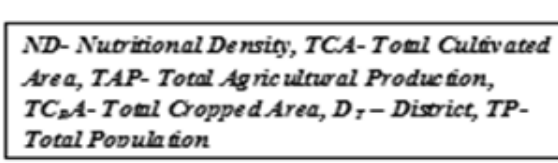 \\
\hline
\end{tabular}

The selected area for the present study constitutes the Interfluve of Ajay-Mayurakshi River, parts of Birbhum district, West Bengal bounded by the river Ajay in the south and the Mayurakshi in the north (parts of Birbhum district, West Bengal). Geographically the area is situated within $23^{\circ} 32^{\prime} \mathrm{N}$ to $23^{\circ} 57^{\prime} \mathrm{N}$ latitudes and $87^{\circ} 05^{\prime} \mathrm{E}$ to $87^{\circ} 52^{\prime} \mathrm{E}$ longitudes respectively, comprising an area about $2569.86 \mathrm{sq}$. km. It includes Khoyrasol, Rajnagar, Dubrajpur, Suri (I and II), Sainthia of Suri (Sadar) Subdivision (Approx. area of 1391.69 Sq.km) and Illambazar, Labhpur, Nanoor andSriniketan blocks of Bolpur Subdivision (Approx. area of 1178.17 Sq.km) of Birbhum district, West Bengal. The area is literally characterize by typical lateritic tract (Rarh Bhumi) delimited by deltaic plain in the east and plateau fringe in the west of West Bengal. The general relief inclined from west to east and the west is slightly rugged and much more undulating in comparison to eastern deltaic plain. The climate is dry tropical type and rainfall decreases from east to west. In consequence of the present problem, the area is not so develop in agriculture and usually monocropped area is characteristic in this region. A considerable portion of the area is unculturable. With respect to agro-climatic environment the area can be classed into following agro-climatic zones. 


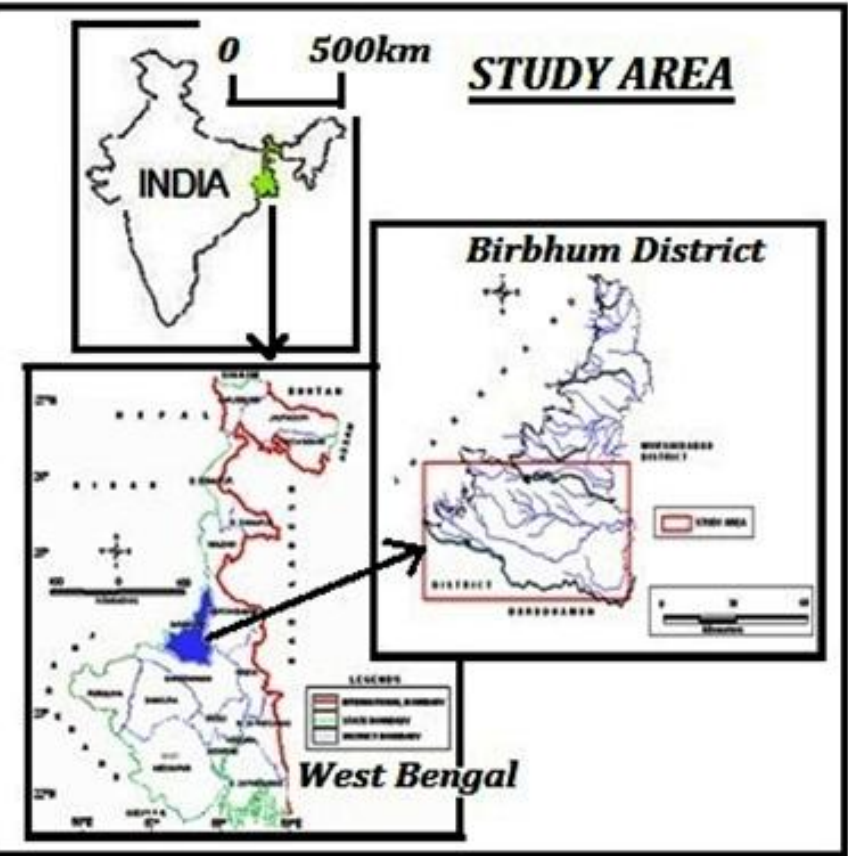

Fig. 01- Location of the Study Area

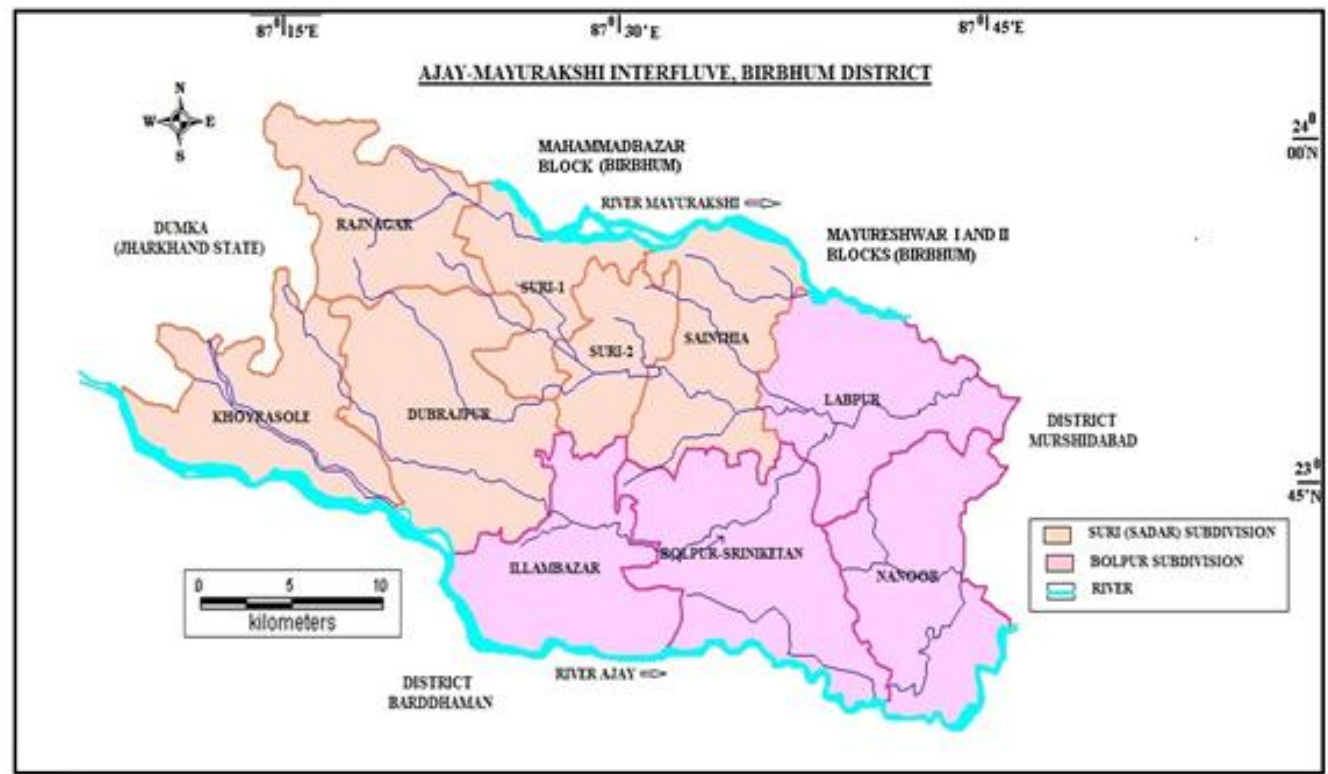

Fig. - 02 - Ajay-Mayurakshi Interfluve, Birbhum, West Bengal

Fig.- 02 - Source: Compiled by the Author from Administrative Atlas, NATMO, SOI, INDIA

\section{Study Area}

The selected area for the present study constitutes the Interfluve of Ajay-Mayurakshi River, parts of Birbhum district, West Bengal bounded by the river Ajay in the south and the Mayurakshi in the north (parts of Birbhum district, West Bengal). Geographically the area is situated within $23^{\circ} 32^{\prime} \mathrm{N}$ to $23^{\circ} 57 \mathrm{~N}$ latitudes and $87^{\circ} 05^{\prime} \mathrm{E}$ to $87^{\circ} 52^{\mathrm{E}}$ longitudes respectively, comprising an area about $2569.86 \mathrm{sq}$. km. It includes Khoyrasol, Rajnagar, Dubrajpur, Suri (I and II), Sainthia of Suri (Sadar) Subdivision (Approx. area of 1391.69 Sq.km) and Illambazar, Labhpur, Nanoor andSriniketan blocks of Bolpur Subdivision (Approx. area of 1178.17 Sq.km) of Birbhum district, West Bengal. The area is literally characterize by typical lateritic tract (Rarh Bhumi) delimited by deltaic plain in the east and plateau fringe in the west of West Bengal. The general relief inclined from west to east and the west is slightly rugged and much more undulating in comparison to eastern deltaic plain. The climate is dry tropical type and rainfall decreases from east to west. In consequence of the present problem, the area is not so develop in agriculture and usually mono cropped area is characteristic in this 
region. A considerable portion of the area is unculturable. With respect to agro-climatic environment the area can be classed into following agro-climatic zones

Gangetic Alluvial zone comprises eastern and south eastern blocks of the district. The soil is mainly alluvial, very deep, medium fine to medium texture, neutral mildly alkaline in $\mathrm{pH}$, base saturation is moderately high, $\mathrm{N}$ and $\mathrm{P}$ status are moderate to moderately low and $\mathrm{K}$ is moderate to high. So, a wide variety of crop is cultivated in this region, but productivity is low.

2. Vindhyan Alluvial Zone: comprises northern and central blocks (such as - Suri- I and II, Md. Bazar etc.). Depth of soil is considerably high, texture is moderate to fine. In most cases the soil $\mathrm{p}^{\mathrm{H}}$ is low but $\mathrm{pH}$ increases with depth. Ground water deeply placed, low in bases organic matter, medium in Potash. So, agricultural status is moderate to high.

3. Undulating Red and Lateritic Zone: Primarily undulating with mounds and valleys and exhibiting different grades of laterization process in soil formation. Soil is normally well drained, susceptible to erosion due to rapid external drainage, organic carbon, phosphate and potash are significantly low. Agriculture in the study area is mostly depending on rain water. Ground water is not easily and economically harvestable. Prevalence of moisture stress on standing Kharif crops during the late monsoon period is very common. The Agro-climatic condition of the study area is mainly influenced by the presence of a number of rivers, rivulets, dams and barrages. The temperature varies from $12.7^{\circ} \mathrm{C}$ to $28.3^{\circ} \mathrm{C}$ in winter and from $25.5^{\circ} \mathrm{C}$ to $41.5^{\circ} \mathrm{C}$ in summer. The average rainfall is $1430 \mathrm{~mm}$ and the soil is acidic in nature.

\section{Results and Discussions}

Birbhum is one of the 19 districts of West Bengal sharing $\mathbf{5 . 1 2}$ per cent of the land area of the state but 3.76 per cent of its total population, indicating the density of population 663 per square $\mathrm{km}$. in the district where the state records 903 persons per sq. km. Between 1991 and 2001 census years, the population of Birbhum increased from 2,555,664 to 3,012,546 registering 18\% decadal growth rate, which is marginally higher than the growth rate of population in West Bengal as a whole (17.8 per cent). According to the 2011 census, Birbhum district had a population of 3,502,404 roughly. The district has a population density of 771 persons per square kilometre. Its population growth rate over the decade 2001-2011 was $16.15 \%$. But the growth and distribution of population in the area is not uniform due to unfavourable environmental conditions, so, the study area noticed highly variable and uneven spatial distribution of population in the studied area.

Fig. 03: Growth of Population in Ajay-Mayurakshi Interfluve (1981-2011)

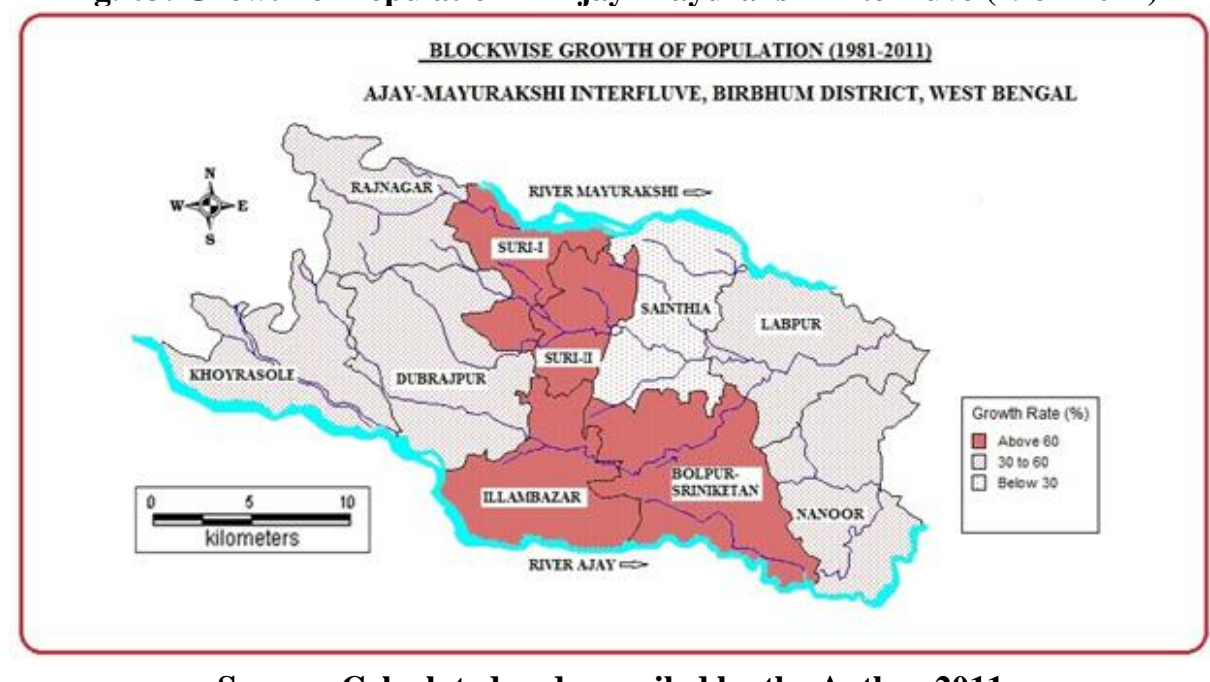

Source: Calculated and compiled by the Author,2011

\section{Trends in population growth}

In most cases, it has been observed that, a large number of populations within the area facing food insecurity having high fertility rates and rapid population growth. This fact increases the challenge of adequately meeting nutritional needs. Food production depends on croplands and water supply, which are under strain as population growth is accelerating. Pressure on limited land resources driven by population growth, virtually, creating pressure on cropland resulting forced expansion of cropland. This often involves destruction of vital forest resources or overexploitation of arable land. Table 1 reveals that, total population of the study area (AjayMayurakshi Interfluve) increased from 1,095,079 in 1981 to 1,598,612 in 2011 at the growth rate of $45.98 \%$. The highest growth rate of population (81.31\%) from (1981-2011), has been observed in Suri-I block, followed by Bolpur-Sriniketan $(70.30 \%)$ block. 
Impact of Population Growth on Nutritional Density and Food Security - A Spatio-Temporal ....

Table 1: Block wise Population Distribution and Decadal Growth Rate (\%)

\begin{tabular}{|c|c|c|c|c|c|c|c|c|c|}
\hline \multirow{2}{*}{$\begin{array}{l}\text { SL. } \\
\text { No. }\end{array}$} & \multirow{2}{*}{ Blocks } & \multicolumn{4}{|c|}{$\%$ of Total Population } & \multicolumn{3}{|c|}{ Decadal Growth Rate (\%) } & \multirow{2}{*}{$\begin{array}{c}\begin{array}{c}\text { Overall Growth of } \\
\text { Population }(\%)\end{array} \\
(1981-2011)\end{array}$} \\
\hline & & 1981 & 1991 & 2001 & 2011 & $(1981-91)$ & (1991-01) & $(2001-11)$ & \\
\hline 1 & Suri - I & 2.93 & 3.03 & 3.2 & 3.18 & 26.05 & 24.61 & 15.43 & 81.31 \\
\hline 2 & Suri -II & 2.51 & 2.55 & 2.56 & 2.5 & 24.05 & 18.19 & 13.51 & 66.42 \\
\hline 3 & Sainthia & 7.32 & 6.07 & 5.85 & 5.58 & 1.11 & 13.55 & 10.92 & 27.35 \\
\hline 4 & Dubrajpur & 6.4 & 5.26 & 5.28 & 5.18 & 0.15 & 18.29 & 14.13 & 35.21 \\
\hline 5 & Khoyrasole & 4.81 & 4.78 & 4.49 & 4.38 & 21.09 & 10.78 & 13.32 & 52.01 \\
\hline$\overline{6}$ & Rajnagar & 2.58 & 2.41 & 2.31 & 2.23 & 13.67 & 13.26 & 11.88 & 44.03 \\
\hline 7 & Bolpur & 7.94 & 5.95 & 5.83 & 5.78 & 11.64 & 15.42 & 15.42 & 70.30 \\
\hline 8 & Illambazar & 4.73 & 4.73 & 4.8 & 4.82 & 22.04 & 19.52 & 16.76 & 67.37 \\
\hline 9 & Labpur & 6.21 & 6.01 & 5.87 & 5.76 & 17.99 & 15.15 & 14.19 & 55.15 \\
\hline \multirow[t]{2}{*}{10} & Nanoor & 6.82 & 6.59 & 6.43 & 6.24 & 17.78 & 15.47 & 12.83 & 52.96 \\
\hline & District & & & & & 21.94 & 17.88 & 16.26 & 67.11 \\
\hline
\end{tabular}

Source : District Census of West Bengal, Birbhum (1981,1991,2001 and 2011)

Other blocks namely Suri-II (66.42\%), Khoyrasole (52.01\%), Illambazar (67.37\%), Labpur (55.15\%) and Nanoor $(52.96 \%)$ also found higher growth rate than study area average. Even, three blocks namely Suri - I (81.31\%), Bolpur- Sriniketan $(70.30 \%)$ and Illambazar $(67.37 \%)$ having higher population growth rate with compare to the whole district $(67.11 \%)$. Sriniketan $(70.30 \%)$ block. Five other blocks namely Suri - II $(66.42 \%)$, Khoyrasole (52.01\%), Illambazar (67.37\%), Labpur $(55.15 \%)$ and Nanoor $(52.96 \%)$ also found higher growth rate than study area average. Even, three blocks namely Suri - I (81.31\%), Bolpur- Sriniketan $(70.30 \%)$ and Illambazar $(67.37 \%)$ having higher population growth rate with compare to the whole district $(67.11 \%)$.

\section{Nutritional Density}

The Nutritional Density is considered very important for assessing man-land ratio between total population and total cultivated area and is expressed in terms of persons per sq. hectares of total cultivated land. Nutritional Density is also a meaningful index for calculating man-land ratio particularly for countries whose economies are largely dependent on agriculture.

Fig. 04: Block wise Status of Nutritional Density in Ajay-Mayurakshi Interfluve (1981)

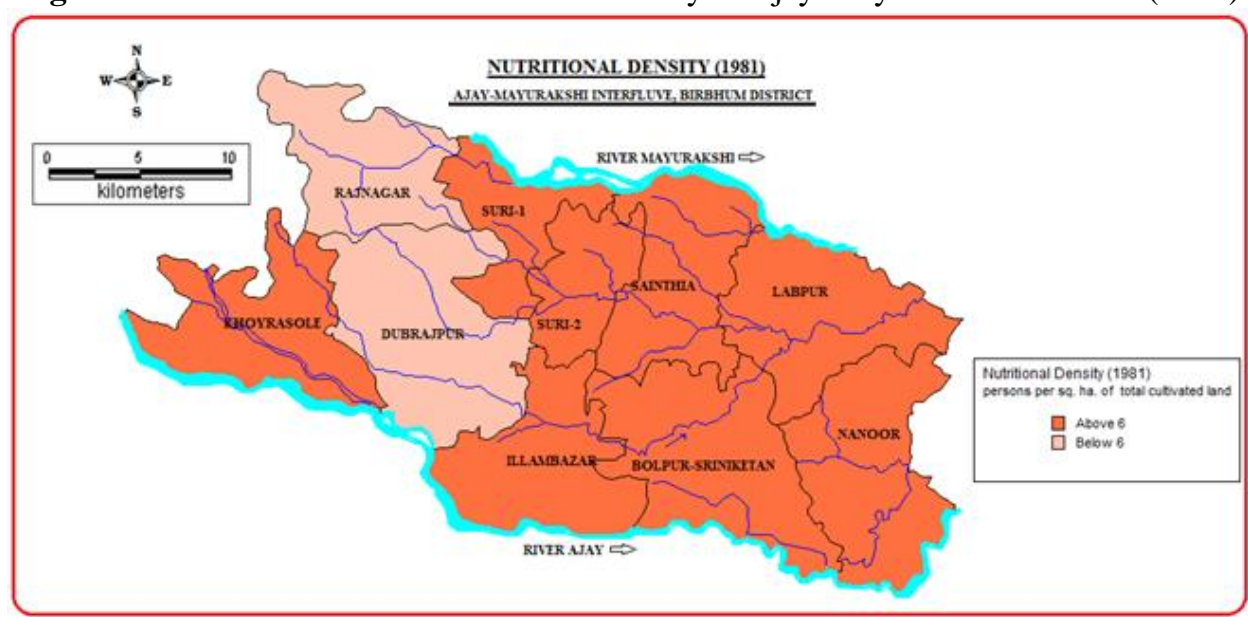

Source: Both maps are Calculated and compiled by the Author (2011) 
Fig. 05: Block wise Status of Nutritional Density in Ajay-Mayurakshi Interfluve (2011)

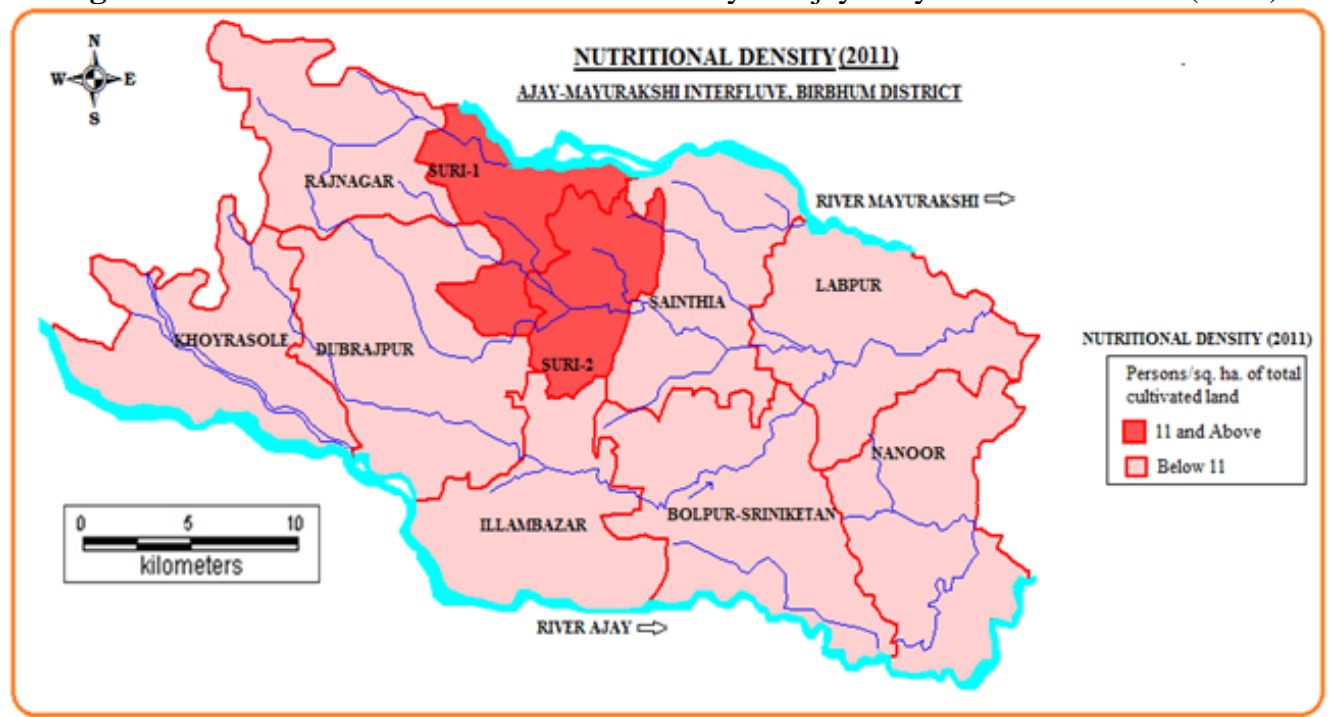

Table: 2 : Nutritional Density of Ajay-Mayurakshi Interfluve (1981-2011)

\begin{tabular}{|c|c|c|c|c|c|c|c|c|c|c|c|c|c|}
\hline \multirow{2}{*}{$\begin{array}{l}\text { SL. } \\
\text { No. }\end{array}$} & \multirow[b]{2}{*}{ Blocks } & & \multicolumn{3}{|c|}{ Total Population('000) } & \multicolumn{5}{|c|}{ Total Cultivated Land (ha.) } & \multicolumn{3}{|c|}{ Nutritional Density } \\
\hline & & 1981 & 1991 & 2001 & 2011 & $\begin{array}{l}(1980- \\
81)\end{array}$ & $\begin{array}{l}\text { (1990 - } \\
91)\end{array}$ & $\begin{array}{l}(2000 \\
-01)\end{array}$ & $\begin{array}{l}\text { (2010- } \\
11)\end{array}$ & $\begin{array}{l}(1980 \\
-81)\end{array}$ & $\begin{array}{l}(1990 \\
-91)\end{array}$ & $\begin{array}{l}(2000 \\
-01)\end{array}$ & $\begin{array}{l}\text { (2010- } \\
11)\end{array}$ \\
\hline 1 & Suri - I & 614.3 & 77430 & 96485 & 111377 & 10022 & 10465 & 10675 & 9940 & 6 & 7 & 9 & 11 \\
\hline 2 & Suri -II & 525.2 & 65153 & 77002 & 87405 & 7072 & 9109 & 9690 & 9316 & 7 & 7 & 8 & \\
\hline 3 & Sainthia & 153.4 & 155104 & 176124 & 195349 & 22273 & 23734 & 28824 & 21415 & 7 & 6 & 6 & 9 \\
\hline 4 & Dubrajpur & 134.2 & 134388 & 158968 & 181437 & 31765 & 33826 & 33000 & 22810 & 4 & 4 & 5 & 8 \\
\hline 5 & Khoyrasole & 100.8 & 122081 & 135239 & 153248 & 21139 & 22237 & 21727 & 19630 & 5 & 5 & 6 & 8 \\
\hline 6 & Rajnagar & 541.4 & 61539 & 69698 & 77979 & 13399 & 14812 & 14312 & 13530 & 4 & 4 & 5 & 6 \\
\hline 7 & Bolpur & 166.5 & 152048 & 175490 & 202553 & 24099 & 25080 & 32260 & 21660 & 7 & 6 & 5 & 10 \\
\hline 8 & Illambazar & 990.6 & 120895 & 144490 & 168709 & 17934 & 19620 & 16740 & 18180 & 6 & 6 & 9 & 9 \\
\hline 9 & Labpur & 130.2 & 153546 & 176803 & 201901 & 21734 & 22412 & 21050 & 20730 & 6 & 7 & 8 & 10 \\
\hline 10 & Nanoor & 143.0 & 168364 & 193788 & 218654 & 22435 & 23067 & 22700 & 22050 & 6 & 7 & 9 & $\overline{10}$ \\
\hline
\end{tabular}

\section{Compiled and calculated by the Author, District Census Handbook, Birbhum, West Bengal} $(\mathbf{1 9 8 1 , 1 9 9 1 , 2 0 0 1}$ and 2011)

Table- 2 reveals significant facts regarding the nutritional density of the study region in relation to population growth and available potential and actual agricultural land. In order to make comparison, the study area has been divided into three categories based on Nutritional density for all four time periods. The study reveals that nutritional density was 6 persons per sq. hectares of cultivated land during early 1980's, which increased to 7 persons in 1991, 9 persons in 2001 and further increased to 11 persons in 2011. The study reveals considerable spatial variation in nutritional density during early 1980's. There were seven blocks namely Suri-I, Suri-II, Sainthia, Bolpur- Sriniketan, Illambazar, Labpur and Nanoor supported nutritional density of 6 persons or more than 6 persons in the 1981; where as it is reduced to merely two blocks having nutritional density of less than district average (11 persons) namely Suri-I and Suri -II in the year 2011. It indicates the increase of population pressure on cultivated lands of the study area during the time period (2001-2011). Every block within the study area has accommodated at an average of at least six persons per sq. hectares of cultivated land at the dawn of $21^{\text {st }}$ century.

\section{Food Availability Status of the study area}

It is evident from Table 3a and 3b) that, during the census year 1981 and 1991, all blocks having food surplus within the study area. Suri-II and Sainthia block with concentration index of 1.03 and 1.09 was observed as high food surplus block in 1981 and 1991 respectively. Although, these blocks do not occupy large geographical area of the district, but the level of agricultural production was higher than the population size 
Impact of Population Growth on Nutritional Density and Food Security - A Spatio-Temporal ....

within the district during 1980-81 and 1990-91.During 2000-01, except Labpur all nine blocks having food deficit status and this block has lower level of concentration index of 0.07. Among food deficit blocks,

Table 3a: Block wise Status of Production Concentration Index and Population Concentration index Computed by the author

\begin{tabular}{|c|c|c|c|c|c|c|c|c|c|}
\hline Sl No. & Blocks & \multicolumn{4}{|c|}{ Concentration Index of Agricultural Production (I) } & \multicolumn{3}{c|}{ Concentration Index of Population (II) } \\
\hline & & $(1980-81)$ & $(1990-91)$ & $(2000-01)$ & $(2010-11)$ & $(1980-81)$ & $(1990-91)$ & $(2000-01)$ & $(2010-11)$ \\
\hline 1 & Suri-1 & 1.07 & 1.26 & 0.43 & 0.67 & 1.03 & 1.07 & 1.16 & 1.14 \\
\hline 2 & Suri-II & 2.44 & 1.76 & 0.66 & 0.88 & 1.41 & 0.87 & 1.23 & 0.94 \\
\hline 3 & Sainthia & 1.94 & 1.95 & 0.67 & 1.25 & 1.03 & 0.86 & 0.7 & 0.77 \\
\hline 4 & Dubrajpur & 1.06 & 0.87 & 0.28 & 0.76 & 0.79 & 0.57 & 0.61 & 0.83 \\
\hline 5 & Khoyrasole & 1.25 & 1.41 & 0.42 & 0.51 & 0.88 & 0.85 & 0.86 & 0.91 \\
\hline 6 & Rajnagar & 1.03 & 1.29 & 0.36 & 0.34 & 0.75 & 0.66 & 0.69 & 0.76 \\
\hline 7 & Bolpur-Sriniketan & 1.57 & 1.41 & 0.54 & 5.83 & 1.18 & 0.86 & 0.69 & 0.9 \\
\hline 8 & Illambazar & 1.81 & 2 & 0.48 & 0.98 & 0.93 & 1.1 & 0.88 & 0.93 \\
\hline 9 & Labpur & 1.64 & 1.76 & 0.96 & 1.41 & 0.97 & 0.98 & 0.89 & 0.93 \\
\hline 10 & Nanoor & 1.84 & 2.12 & 0.64 & 1.16 & 1.07 & 1.31 & 0.93 & 0.82 \\
\hline
\end{tabular}

\begin{tabular}{|c|c|c|c|c|c|c|c|c|c|}
\hline \multirow[t]{2}{*}{ SlNo. } & \multirow[t]{2}{*}{ Blocks } & \multicolumn{4}{|c|}{ Differences in Concentration Indices (I-III) } & \multicolumn{4}{|c|}{ Food Availability Status (Surp/us/Deficit) } \\
\hline & & (1980-81) & $(1990-91)$ & $(2000-01)$ & (2010-11) & (1980-81) & (1990-91) & $(2000-01)$ & (2010-11) \\
\hline 1 & Suri - I & 0.04 & 0.19 & -0.73 & -0.47 & Surplus & Surplus & Deficit & Deficit \\
\hline 2 & Suri -II & 1.03 & 0.89 & -0.57 & -0.06 & Surplus & Surplus & Deficit & Deficit \\
\hline 3 & Sainthia & 0.91 & 1.09 & -0.03 & 0.48 & Surplus & Surplus & Deficit & Surplus \\
\hline 4 & Dubrajpur & 0.27 & 0.3 & -0.33 & -0.07 & Surplus & Surplus & Deficit & Deficit \\
\hline 5 & Khoyrasole & 0.37 & 0.56 & -0.44 & -0.04 & Surplus & Surplus & Deficit & Deficit \\
\hline 6 & Rajnagar & 0.28 & 0.63 & -0.33 & -0.42 & Surplus & Surplus & Deficit & Deficit \\
\hline 7 & Bolpur - Sriniketan & 0.39 & 0.55 & -0.15 & 4.93 & Surplus & Surplus & Deficit & Surplus \\
\hline 8 & Illambazar & 0.88 & 0.9 & -0.4 & 0.05 & Surplus & Surplus & Deficit & Surplus \\
\hline 9 & Labpur & 0.67 & 0.78 & 0.07 & 0.48 & Surplus & Surplus & Surplus & Surplus \\
\hline 10 & Nanoor & 0.77 & 0.81 & -0.029 & 0.34 & Surplus & Surplus & Deficit & Surplus \\
\hline
\end{tabular}

Table 3b: Block wise Food Availability Status in Ajay-Mayurakshi Interfluve

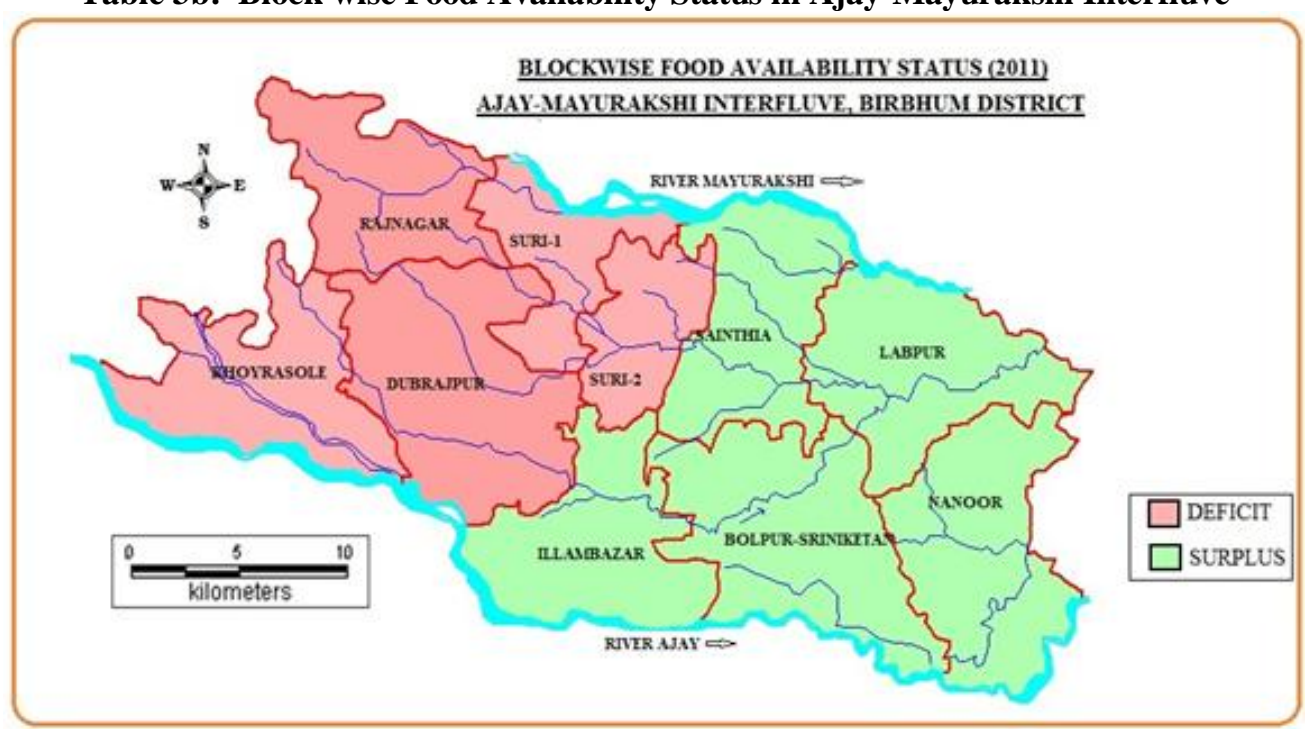

Fig. 06: Block wise Food Availability Status (2010-11): Ajay-Mayurakshi Interfluve

within the study area, values of concentration index range between -0.03 to -0.73 . During 2010-11, only five blocks observed as food surplus namely Sainthia, Bolpur-Sriniketan, Illambazar, Labpur and Nanoor and value of concentration index ranges between 0.48 to 4.93 , due to sufficient agricultural production. Enhanced 
production is likely to come from higher level of crop productivity, cropping diversity and use of modern technology and practices in agriculture.

Relationship between Concentration Index of Population and Agricultural Production:

From the value of Table $3 a$, and $3 b$, it has been depicted that, there is a strong positive relationship between the two variables (Concentration Index of Agricultural Production and Concentration Index of Population) and it has been depicted by the value of Correlation Coefficient of four different consecutive census years. But, the trend in progressive census years is declining; which indicates the closeness of the relationship of two variables decreasing day by day and with the tremendous increase of population growth, agricultural production is not increasing or slightly increasing, which will be creating regional imbalances in future.

Fig 07 - Status of correlation and Temporal trend shown by ' $r$ ' values between variables

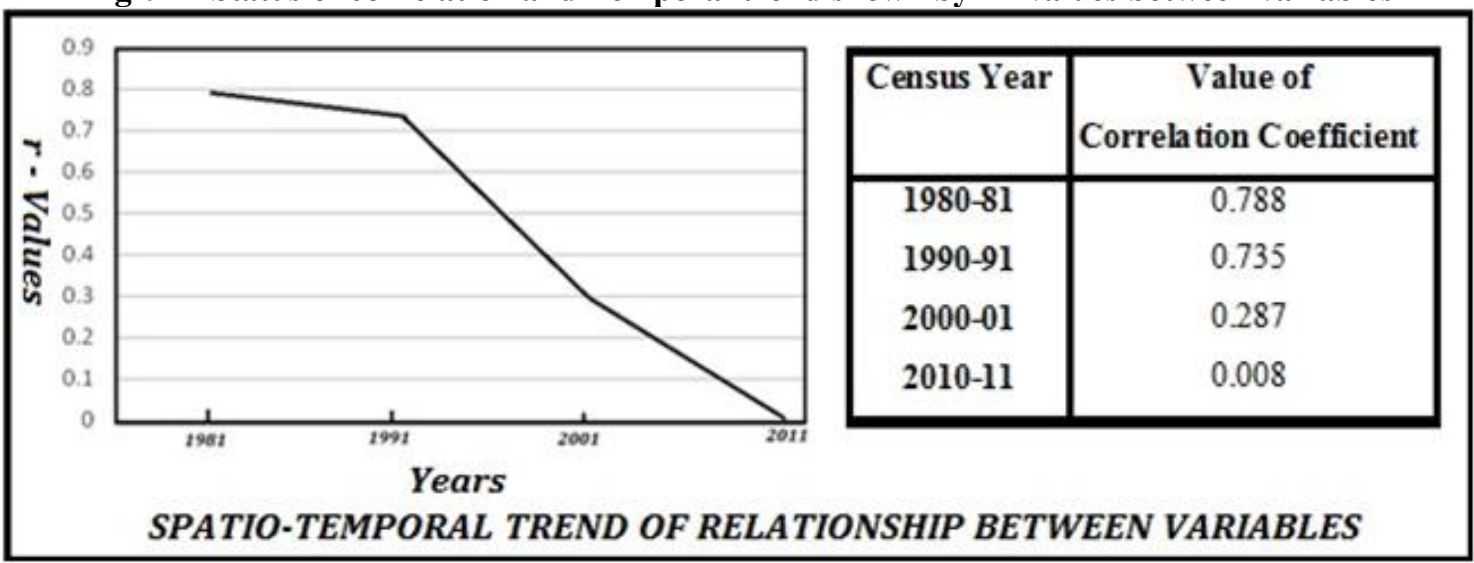

Source: Calculated and compiled by the Author, 2011

\section{Major Findings:}

Observation, analysis, presentation and interpretation, finally, reveal some significant facts on the present problem in relation to the accelerating rate of growth trend in the study region like other region in India. The present paper reveals that population growth has continuous increasing trend whereas supply of food and especially, availability of nutritious food is barely observed. A large number of populations are devoid of proper quality and quantity of food and it has been observed that the distribution of population represents inverse correlation between area and availability of food, because geographically small blocks are supporting large number of population which had no such capability. The nutritional density has high rising trend from 6 persons in 1981 to 11 persons in 2011 in the study area. The rise in Nutritional density may safely be taken as an indication of growing pressure on agricultural lands. It may be inferred from the study that, the blocks which are located in the western Fringe of the district have been prone to food security problem due to some constrains directly or indirectly affecting agricultural production system, such as, highly undulating plateau terrain, poor soil fertility status, and lack of irrigation facility. In the western flank of the area Iron-manganese concretions and strong brown to dark brown mottles are present in the subsoil, makes it infertile and so, production and productivity both are very low to meet the demand of quality and quantity of food of the existing population. Soil is strongly acidic in nature and light too medium in texture. This area is also very much degraded as forest land is cleared unscientifically, so, soils are prone to moderate to high erosion and may be kept under grassland and forest; partly cultivated to paddy, pulses and vegetables. The cultivation in kharif season can be done with proper soil conservation measures.

\section{Conclusion and Suggestion}

Due to degraded and Unfavourable nature of land and Accelerating pressure of growing population in the study area, there is need to increase the effective agricultural land (Though land resource is limited) and its productivity to curb the growing population pressure for adequate supply of nutritious and quality food to its inhabitants. The challenge of meeting the food requirement of an ever increasing population can only be met by practicing sustainable agriculture, protecting natural resources from being degraded and polluted and using production technologies that conserve and enhance the natural resource base of crops in future. The following points are to be added as conclusive and suggestive measures-

a) Ajoy-Mayurakshi interfluve zone is regarded as a distinct as well as significant agro economic zone in relation to environment, population and development. It also displayed diverse biotic and abiotic conditions which suggest variable population, production and economic growth in relation to quality and quantity. 
b) Being a backward region the study area displays moderate to high population growth rate like other parts in India and West Bengal, but growth rate of productive land and multiple cropping land are so low that the regions, virtually, unable to supply the proper amount and quality of food for the people.

c) A large number of people are leaving in the unproductive areas where concentration of productive land is very less, where large number of people does not get sufficient nutritious food. Only some exceptional areas where agro-climatic is favourable, the people can meet their demand of quantity and quality food.

d) A very interesting fact is that, in the developed to moderately developed regions, in the study area, although people are getting food, but many of them are not in a position to make it nutritious, So, although the density of population is moderate to high but the nutritional density is not so significant due to the dominancy of unfavourable agro-environmental and socio-economic factors. It has been observed, that in the year extending from 2000 to 2011 a large areas are suffering from deficit food supply, that suggest the struggling stages of food supply which has no scope to maintain or make it nutritious at the same time.

However, it is to be recommended that, govt. should take effective policies for sustainable area development programme, as agriculture is not so popularly concentrated in these tracts. Only, scattered tracts are available for mono cropping purpose, where production and productivity both are less, but for meeting the demand of growing population, alternative means of occupation should be arranged for holistic socio-economic development.

\section{Acknowledgement:}

The author like to extend her deep gratitude to all personals, Govt. and Non-organisations and especially, local people for their valuable suggestions and help in preparing this research paper. Thanks are due to local B.D.O. and local Panchayet personals of the respective blocks for their constant help and suggestions.

\section{References}

[1]. Ashgate. S, M. (2010), Diversification and Resource Management: Re-focussing the Role of Agriculture, Revamping Food Procurement and Pricing Policies. Yojana, Vol.54 (October) pp.10-13.

[2]. Bhalla, G.S. and Gurmail Singh (2001), Indian Agriculture: Four Decades of Development, Sage Publications, New Delhi.

[3]. Census of India (1981, 1991, 2001 and 2011), Primary Census Abstract, West Bengal.

[4]. Challenges of Food Security and Its Management (2011), National Rainfed Area Authority (NRAA), Planning Commission, Government of India, New Delhi.

[5]. Chand, R., Garg, S. and Pandey, L.(2009), Regional Variation in Agricultural Productivity - A District Level Study. Publ. NCAP, DPS Marg, Pusa, New Delhi -110012 , India.

[6]. Chandna, R.C. (2006,) Geography of Population - Concepts, Determinants and Patterns, 6th Edition, Kalyani Publishers, New Delhi.

[7]. Clarke, J. (1966), Population Geography, Oxford: Porgamon Press, London

[8]. Comprehensive District Agriculture Plan for Birbhum District (2012), Deputy Director of Agriculture, Birbhum, West Bengal, India.

[9]. Dev, S.M. and Sharma, A. N. (2010), Food Security in India: Performance, Challenges and Policies, Oxfam India working papers series, OIWPS - VII, New Delhi.

[10]. Dev, S.M. (2003), "Right to Food in India” Working Paper no. 50, Centre For Economic and Social Studies, Hyderabad.

[11]. Dev, S., K.P.Kannan and Nira Ramachandran (2003), Towards a Food Secure

[12]. Dreze, J. (2004), "Democracy and Right to Food", Economic and Political Weekly, April 24, Vol. 39.

[13]. FAO ( 2010), "The Impact of Global Food Policy Report (2011), International Food Policy Research Institute, Washington, DC 20006-1002, USA.

[14]. FAO (2009), The State of Food Insecurity in the World. Food and Agriculture Organisation of the United Nations, Rome.

[15]. FAO. (2010), The State of Food Insecurity in the World 2010.

[16]. Gopalan, C. (1995), "Towards Food and Nutritional Security", Economic and Political Weekly, Vol. 30, No. 52, December 1995, pp. A-134-141.

[17]. Gulati, A., Gujral, J., Nandakumar, T., Jain, S., Anand, S., Rath,S. And Joshi, P. (2012), National Food Security Bill : Challenges and Options, Discussion Paper No. 2, December 2012, Commission for Agricultural Costs and Prices, Department of Agriculture \& Cooperation, Ministry of Agriculture, Government of India.

[18]. Hunter, W.W. (2001), Statistical account of Birbhum, Department of Higher Education, Government of West Bengal, Calcutta.

[19]. Krishna Rao, Y.V. (ed.) (2000), New Challenges Facing Indian Agriculture, Visalaandhra Publishing House, Hyderabad.

[20]. Kumar, P.(2010) Food Security : The Challenges Ahead. Yojana, Vol.54 (October) pp 27-31.

[21]. Kumar, V.S. (2010), Securing Food for All. Yojana, Vol.54 (October) pp 36-39.

[22]. Majumdar, D. (1975), West Bengal district gazetteers (Birbhum).

[23]. Malley, O.O. (1996), Bengal district gazetteers, Birbhum, Government of West Bengal.

[24]. Mandal, R., Uyanga, J. And Prasad, H. (2007), Introductory Methods In Population Analysis, Concept Publishing Company, New Delhi.

[25]. Of Global Change and Urbanization on Household Food Security, Nutrition and Food Safety." http://www.fao.org/ag/agn/nutrition/national_urbanization_en.stm.

[26]. Premi, M.K. (2009), India's Changing Population Profile, National Book Trust,India.

[27]. Radhakrishna , R. (1991), "Food and Nutrition: Challenges for Policy", Journal of the Indian Society of Agricultural Statistics, Vol. 43, No. 3, pp. 211-227.

[28]. Radhakrishna, R. (2002), "Food and Nutrition Security" in Kirit S. Parikh and R. Radhakrishnas (eds.) India Development Report, 2002, Oxford University Press.

[29]. Rahal, A. and Shivay, Y.S. (2010), Increasing Agricultural Production In India. Kurukshetra, Vol.58, No. 9 (July) pp.19-24.

[30]. Rao, C.H.H. and R.Radhakrishna (1997), "National Food Security: A Policy Perspective for India", Plenary paper, 27th International Conference of Agricultural Economists, August 10-16, Sacramento, California and published in G.H. Peter and J.V. Braun (ed.) Food Security, 